\title{
Sprawozdanie z Ogólnopolskiej Konferencji Naukowej Ochrona matżeństwa i rodziny w nauczaniu i ustawodawstwie papieża Franciszka i Zjazdu Stowarzyszenia Kanonistów Polskich. Rzeszów 3-5 września 2018 roku DOI: http://dx.doi.org/10.15633/acan.2782
}

W dniach 4 i 5 września 2018 roku w Instytucie Teologiczno-Pastoralnym im. św. Józefa Sebastiana Pelczara w Rzeszowie, pod patronatem Jego Ekscelencji ks. bpa dra Jana Wątroby, biskupa diecezji rzeszowskiej, odbyły się Ogólnopolska Konferencja Naukowa Ochrona małżeństwa i rodziny w nauczaniu i ustawodawstwie papieża Franciszka oraz Zjazd Stowarzyszenia Kanonistów Polskich.

Konferencję otworzył ks. bp dr Jan Wątroba, biskup diecezji rzeszowskiej, który ciepło przywitał wszystkich uczestników tego naukowego spotkania. Po nim głos zabrał ks. prof. dr hab. Józef Krukowski, prezes Stowarzyszenia Kanonistów Polskich, które było głównym organizatorem wydarzenia. Wręczył on napisane w języku Kościoła, to jest po łacinie, dyplomy honorowego członkostwa w Stowarzyszeniu ks. bpowi Marianowi Buczkowi (Charkow-Zaporoże) oraz ks. bpowi drowi Janowi Wątrobie (Rzeszów).

Sesja I, moderowana przez ks. bpa dra hab. Artura Mizińskiego, sekretarza generalnego KEP, składała się z dwóch referatów. Pierwszy z nich wygłosił ks. bp. dr Jan Wątroba: Informacje dotyczące nowej instrukcji KEP poświęconej problematyce matżeństwa i rodziny. Dokument ten, jeszcze niepromulgowany, poświęcony został zagadnieniom związanym z posynodalną adhortacją apostolską Amoris laetitia ojca świętego Franciszka, szczególnie zaś najbardziej kontrowersyjnej kwestii przyjmowania Eucharystii przez osoby żyjące w związkach niesakramentalnych. Prelegent zwrócił uwagę na to, że omawiany problem nie został w instrukcji ostatecznie rozwiązany.

Drugi referat sesji I przygotowany został przez ks. dra hab. Leszka Adamowicza (KUL) oraz ks. dra hab. Piotra Majera, prof. UPJPII: Prace KEP nad nowa polską regulacją prawa dotyczącego przygotowania do małżeństwa. Referat został podzielony na dwie części, z których pierwszą zaprezentował ks. dr hab. Majer, a drugą ks. dr hab. Adamowicz. Część I: KEP przygotował nową instrukcję dotyczącą przygotowania do małżeństwa i od marca 2017 roku czeka ona na recognitio Stolicy Apostolskiej. Instrukcja dotyczy egzaminu narzeczonych i pomija sprawy związane z przygotowaniem dalszym i bliższym do małżeństwa. W dokumencie znalazły miejsce nowe rozwiązania prawne: wspólna modlitwa oraz złożenie 
przysięgi przez nupturientów przed spisywaniem protokołu przedmałżeńskiego; o dyspensy i pozwolenia proboszcz ma występować do kurii nie później niż dwa miesiące przed planowanym zawarciem małżeństwa; ważność protokołu ustala się na rok - po tym okresie należy go powtórzyć; rezygnacja z zapisu o niepamiętnym zwyczaju zawierania małżeństwa w parafii panny młodej; wydanie metryki chrztu ma zostać odnotowane na marginesie księgi chrztów. Część II została poświęcona poszczególnym przeszkodom, wadom zgody małżeńskiej, formie kanonicznej oraz małżeństwom osób o różnej przynależności kościelnej. Tutaj do nowości należy zaliczyć: obowiązek nawiązania przez proboszcza katolickiego osobistego kontaktu $\mathrm{z}$ duchownym strony niekatolickiej oraz nakaz, by świadkami małżeństwa byli katolicy.

Sesję I zakończyła dyskusja, w której prócz prelegentów udział wzięli: ks. prof. dr hab. Ginter Dzierżon (UKSw), ks. prof. dr hab. Wojciech Góralski (uksw), ks. dr Waldemar Gałązka (Sandomierz), ks. prof. dr hab. Tomasz Rozkrut (UPJPII) oraz ks. dr Krzysztof Dziub (Częstochowa). Po dyskusji miała miejsce przerwa kawowa.

Sesji II przewodniczył ks. bp dr Krzysztof Nitkiewicz, biskup diecezji sandomierskiej. Sesja ta składała się z trzech prelekcji. Jako pierwszy wystąpił dr hab. Paweł Sobczyk, prof. uo, z referatem Nowe rozwiqzzania dotyczące ochrony i opieki nad małżeństwem i rodzinq. W swym przedłożeniu autor starał się odpowiedzieć na trzy zasadnicze pytania: Czy istnieje potrzeba nowych rozwiązań dotyczących ochrony i opieki nad małżeństwem i rodziną w prawie polskim? Czy mamy już jakiejś nowe rozwiązania tej kwestii? Jak prawodawca realizuje konstytucyjną ochronę małżeństwa i rodziny? Istotną kwestią poruszoną przez autora była inicjatywa (projekt) nowego kodeksu rodzinnego.

Drugą osobą, która zabrała głos w sesji II, niezupełnie w charakterze prelegenta, był Mikołaj Pawlak, dyrektor Departamentu Spraw Rodzinnych i Nieletnich Ministerstwa Sprawiedliwości. Mówił on o reformie procesu rozwodowego, który każdorazowo, w przypadku małżeństw mających małoletnie dzieci, będzie miał zostać poprzedzony rodzinnym postępowaniem informacyjnym. Polegać będzie ono na tym, by w obecności sędziego na sali rozpraw mediator podjął próby pojednania stron, a w przypadku braku takiej możliwości podjął próby pokojowego rozwiązania kwestii związanych z alimentami, wychowaniem dzieci i wszystkim tym, co związane jest z małoletnimi dziećmi stron.

Trzecią osobą, która wystąpiła podczas II sesji, był ks. prof. dr hab. Wojciech Góralski, który wygłosił referat Brak rozeznania oceniającego (kan. 1095, $2^{\circ} \mathrm{KPK}$ ). 
Czy norma jest wystarczająco rozpoznawana? Kwestia ta została już wcześniej bardzo szeroko omówiona przez autora w licznych publikacjach monograficznych i na łamach wielu periodyków naukowych.

Następnie przystąpiono do dyskusji, w której z audytorium głos zabrali: ks. dr hab. Andrzej Wójcik (UPJPII), ks. prof. dr hab. Ryszard Sztychmiler (UWM), ks. dr Rafał Wierzchanowski (Tarnów) oraz adw. Teresa Orłowska.

Po dyskusji przyszedł czas na obiad, a po nim nastąpiło walne zebranie Korpusu Adwokatów Kościelnych w Polsce, na którym odbyły się wybory nowego zarządu, w wyniku których przewodniczącym Korpusu został ks. prof. dr hab. Ryszard Sztychmiler.

W sesji III, prowadzonej przez ks. bpa Antoniego Dziemianko, sekretarza generalnego Konferencji Katolickich Biskupów Białorusi oraz biskupa diecezji pińskiej, głosząc referaty czynny udział wzięli: ks. prof. dr hab. Ginter Dzierżon: Fides et sacramentum. Wiara nupturienta a ważność małżeństwa oraz ks. dr hab. Jan Krajczyński, prof. UKsw: Kompetencje sędziego instruktora procesie skróconym. Po krótkiej przerwie w sesji IV moderowanej przez ks. bpa dra Stanisława Stefanka, biskupa seniora diecezji łomżyńskiej, swoje referaty wygłosili ks. prof. dr hab. Tomasz Rozkrut: Rola adwokata w nowym procesie małżeńskim oraz ks. dr hab. Piotr Ryguła, prof. uKsw: Wykluczenie potomstwa jako tytuł nieważności małżeństwa, który ukazał różnicę między wykluczeniem potomstwa a wykluczeniem bonum prolis.

Szczególne zainteresowanie i burzliwą dyskusję po tych dwóch sesjach wywołały tematy związane z instruktorem sprawy i adwokatem w nowym procesie małżeńskim. Jeśli chodzi o instruktora sprawy, prelegent omówił jego urząd, szczególne prawa i obowiązki oraz zasady prawa, jakie winien on uszanować w procesie skróconym. Jeśli zaś chodzi o adwokata, dziekan WPK UPJPII zwrócił uwagę na rolę adwokata in genere, pomoc adwokata w przygotowaniu procesu małżeńskiego oraz konkretne obszary zadań adwokata w procesie małżeńskim - badanie przedprocesowe, wybór odpowiedniej formy procesu, czynny udział w postępowaniu procesowym, złożenie apelacji lub skargi o nieważność wyroku oraz zaangażowanie adwokata na stopniu apelacyjnym. W dyskusji udział wzięli: ks. prof. dr hab. Wojciech Góralski, ks. prof. dr hab. Ryszard Sztychmiler oraz ks. prof. dr hab. Józef Wroceński (uksw).

Po zakończeniu pierwszego dnia konferencji uczestnicy udali się do rzeszowskiej katedry na mszę świętą, której przewodniczył ks. bp dr Jan Wątroba, biskup diecezji rzeszowskiej. Po powrocie miała miejsce skromna kolacja, a po niej nastą- 
piło walne zebranie Stowarzyszenia Kanonistów Polskich, na którym dokonano wyboru nowego zarządu. W wyniku przeprowadzonych wyborów przewodniczącym Stowarzyszenia został ks. prof. dr hab. Józef Krukowski. Po walnym zebraniu w refektarzu oraz w ogrodach Instytutu Teologiczno-Pastoralnego odbył się bankiet.

Drugi dzień konferencji został podzielony na dwie sesje: V i vi. Pierwszej z nich przewodniczył ks. dr hab. Mirosław Sitarz, prof. KUL, drugiej zaś ks. bp Marian Buczek, biskup senior diecezji charkowsko-zaporoskiej. W każdej z sesji wystąpili dwaj prelegenci.

Sesja v: ks. dr hab. Andrzej Pastwa, prof. uś wygłosił referat Bonum coniugum: problem hermeneutyczny orzecznictwa kościelnego, szeroko omawiając wybrane wyroki Trybunału Roty Rzymskiej, w których orzekano nieważność małżeństwa z tytułu wykluczenia tytułowego bonum coniugum. Drugim prelegentem tej sesji był ks. dr Jan Słowiński (UAM), który wygłosił prelekcję: Transeksualizm a niezdolność do zawarcia matżeństwa. Po tych dwóch niezwykle ciekawych wystąpieniach nastąpiła dyskusja, równie ożywiona w stosunku tak do pierwszego, jak i do drugiego referatu. Wzięli w niej udział: ks. dr Waldemar Gałązka, ks. prof. dr hab. Wojciech Góralski, ks. dr hab. Leszek Adamowicz, ks. prof. dr hab. Ryszard Sztychmiler, ks. prof. dr hab. Józef Wroceński, ks. prof. dr hab. Józef Krzywda (UPJPII), ks. bp Marian Buczek (Charkow-Zaporoże) oraz dr Jarosław Kośla (Warszawa). Pomiędzy sesją v i vi miała miejsce przerwa kawowa.

Sesja VI: ks. prof. dr hab. Józef Krzywda wygłosił prelekcję zatytułowaną Szczególne zobowiązania i zadania małżonków względem siebie w perspektywie Kościoła i narodu, zaś po nim głos zabrał ks. dr hab. Piotr Steczkowski, prof. URz, z referatem: Ochrona tożsamości seksualnej osoby w prawie polskim i kanonicznym, w którym obszernie cytując posynodalną adhortację apostolską Amoris laetitia ojca świętego Franciszka, przedstawił kilka tez związanych z ochroną tożsamości seksualnej zilustrowanych przykładami. Oba referaty były niejako kontynuacją bądź też rozszerzeniem wystąpień, które miały miejsce już wcześniej: pierwszy wyraźnie nawiązywał do prelekcji Pawła Sobczyka i Mikołaja Pawlaka, zaś drugi - do referatu Jana Słowińskiego. Po ostatniej sesji odbyła się dyskusja, w której z audytorium udział wzięli: ks. dr hab. Leszek Adamowicz, ks. prof. dr hab. Józef Krzywda, ks. prof. dr hab. Józef Wroceński, s. dr Emmanuela Sikorska (Warszawa), ks. mgr lic. Karol Stach (Kielce), o. dr Andrzej Kukła (Kraków), ks. dr hab. Mirosław Sitarz (KUL). 